
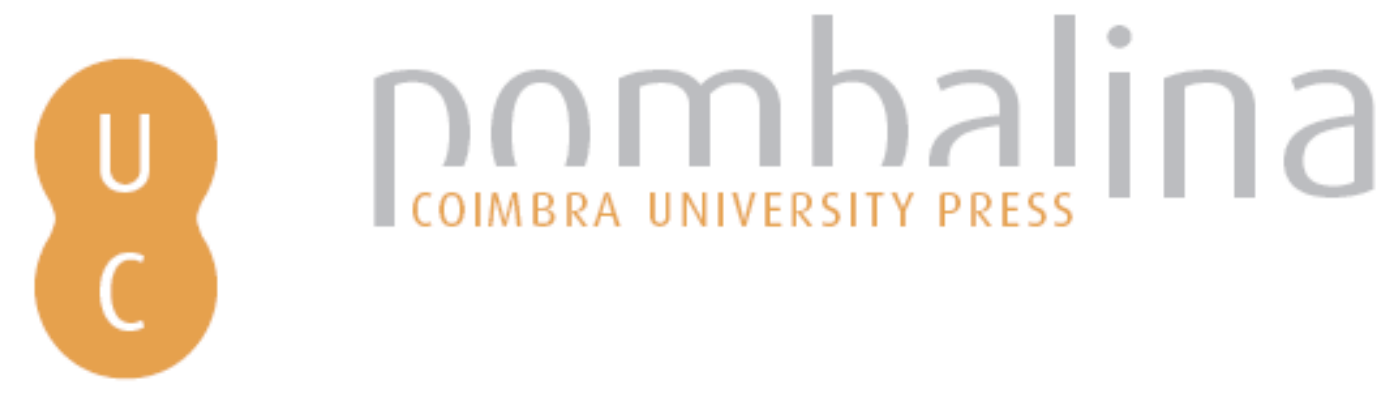

\title{
Eristic strategies in Plutarch's de amore prolis
}

\author{
Autor(es): Roskam, Geert
}

Publicado por: Imprensa da Universidade de Coimbra; Katholieke Universiteit Leuven

URL

persistente: $\quad$ URI:http://hdl.handle.net/10316.2/32109

DOI: $\quad$ DOI:http://dx.doi.org/10.14195/978-989-26-0462-6_14

Accessed : $\quad$ 26-Apr-2023 13:57:22

A navegação consulta e descarregamento dos títulos inseridos nas Bibliotecas Digitais UC Digitalis, UC Pombalina e UC Impactum, pressupõem a aceitação plena e sem reservas dos Termos e Condições de Uso destas Bibliotecas Digitais, disponíveis em https://digitalis.uc.pt/pt-pt/termos.

Conforme exposto nos referidos Termos e Condições de Uso, o descarregamento de títulos de acesso restrito requer uma licença válida de autorização devendo o utilizador aceder ao(s) documento(s) a partir de um endereço de IP da instituição detentora da supramencionada licença.

Ao utilizador é apenas permitido o descarregamento para uso pessoal, pelo que o emprego do(s) título(s) descarregado(s) para outro fim, designadamente comercial, carece de autorização do respetivo autor ou editor da obra.

Na medida em que todas as obras da UC Digitalis se encontram protegidas pelo Código do Direito de Autor e Direitos Conexos e demais legislação aplicável, toda a cópia, parcial ou total, deste documento, nos casos em que é legalmente admitida, deverá conter ou fazer-se acompanhar por este aviso.

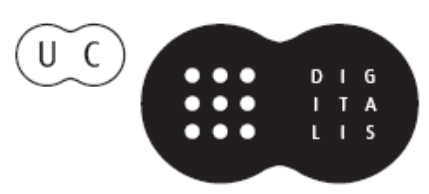




\title{
Puilosophy in Society \\ Virtues and Values in Plutarch
}

\author{
José Ribeiro Ferreira \\ LUC VAN DER STOCKT \\ Maria do Céu Fialho
}

Editors

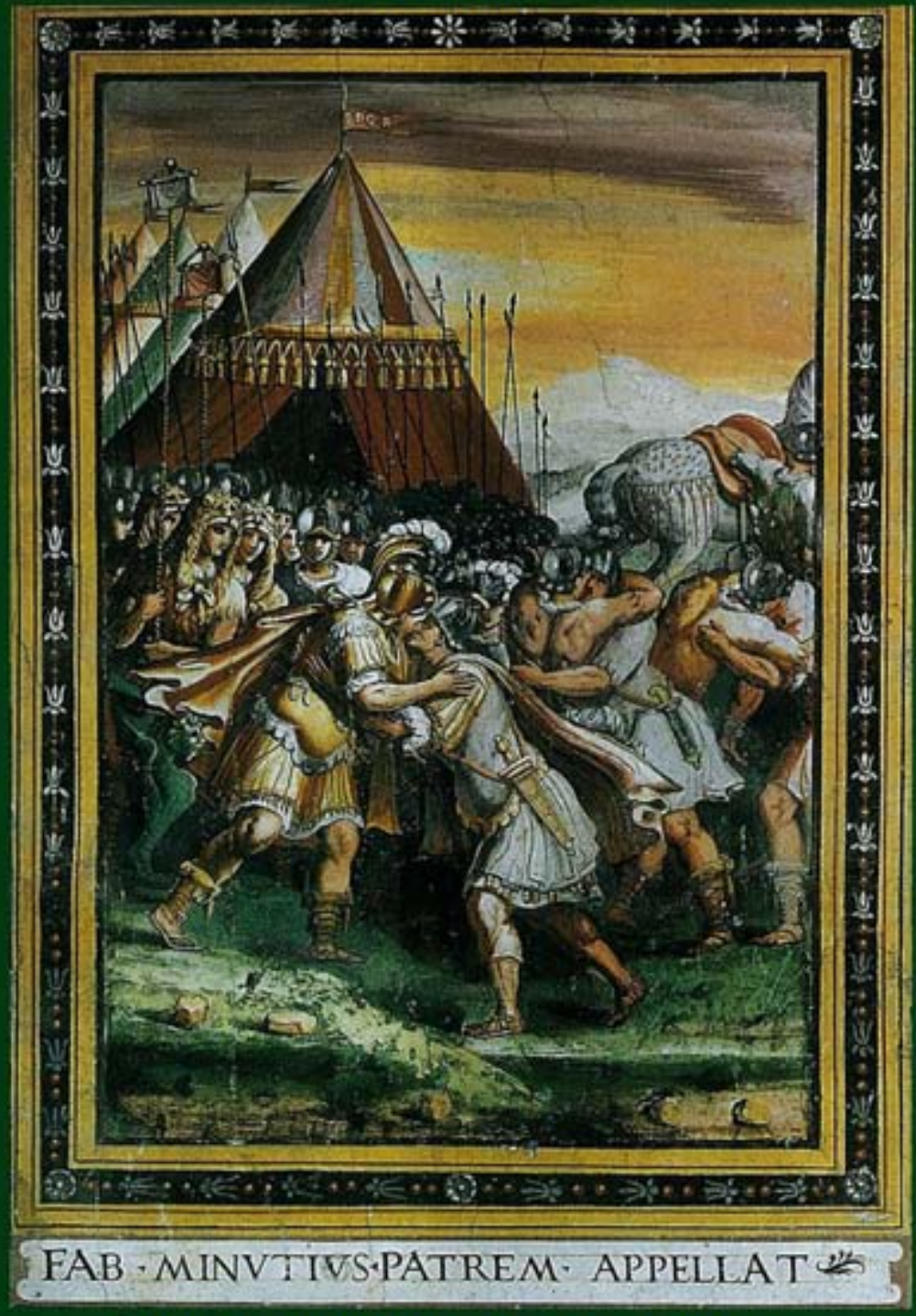

KATHOLIEKE UNIVERSITEIT LEUVEN IMPRENSA DA UNIVERSIDADE DE COIMBRA Leuven-Coimbra, 2008 
(Página deixada propositadamente em branco) 
José Ribeiro Ferreira, Luc van der Stockt \& Maria do Céu Fialho

EDITORS

\section{PhILOSOPHY IN Society}

\section{Virtues and Values in Plutarch}

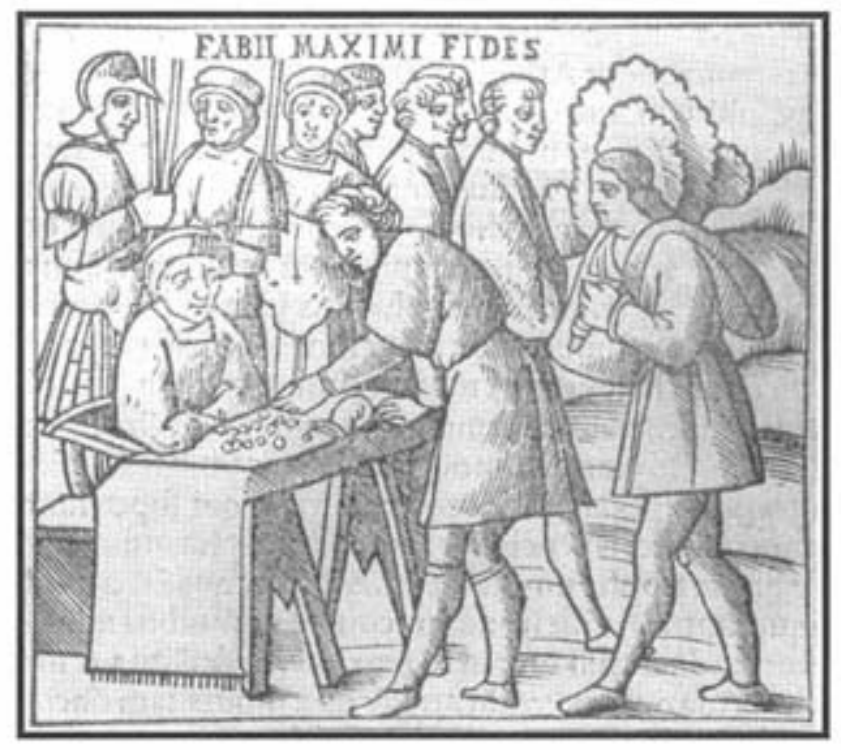

Fabius Maximus' Loyalty

Vitae Plutarchi Cheronei novissime post Jodocum Badium Ascensium longe diligentius repositae maioreque diligentia castigatae, cum copiosiore verioreque indice, nec non cum Aemilii Probi vitis, una cum figuris, suis locis apte dispositis, Venetiis 1516 , fol . 65v

\section{LEUVEN - CoIMBRA \\ 2008}

KATHOLIEKE UNIVERSITEIT LEUVEN

IMPRENSA DA UNIVERSIDADE DE COIMBRA 


\title{
First published 2008
}

\section{(C) Universiteit KATHOlieke Leuven \\ (c) Universidade Coimbra}

\author{
Published by \\ IMPRENSA DA UNIVERSIDADE COIMBRA \\ Imprensa da Universidade de Coimbra \\ Rua da Ilha, $\mathrm{n}^{\circ} 1$ \\ 3000-033 Coimbra (Portugal) \\ Email: imprensauc@ci.uc.pt \\ URL: http://www.uc.pt/imprensa_uc
}

ISBN: 972-989-8074-73-7

Legal Deposit: MA-140-2009

\author{
Printed in Spain by \\ IMAGRAF IMPRESORES, S.A. \\ c/ Nabucco 14 \\ 29006 Málaga \\ Tfno. 952328597
}

\section{Frontispiece:}

Fabius Maximus and Minucius (Francesco da Siena, Grottaferrata, Palazzo Abbaziale). We are grateful to the Archimandrita of the "Monastero Esarchico di Santa Maria di Grottaferrata", P. Emiliano Fabbricatore, for the authorization to reproduce this picture. 


\section{Eristic strategies in Plutarch's De amore prolis \\ GeERT ROSKam \\ K.U.LEUVEN}

\section{A difficult work}

I have no brother, I am like no brother;

And this word 'love', which greybeards call divine, Be resident in men like one another,

And not in me: I am myself alone.

Shakespeare, King Henry VI, Part III, Act III, Sc. 6, 1. 80-83.

If Plutarch would have known those words, he would probably have connected them with the Epicurean point of view, and he would certainly have emended ${ }^{1}$ or rejected them. He would have joined the company of 'greybeards' and would have underlined the importance of community life: man is not 'himself alone', but is as

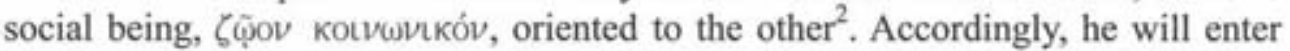
public life, neither in order to gain money or fame, nor giving in to irrational emo-

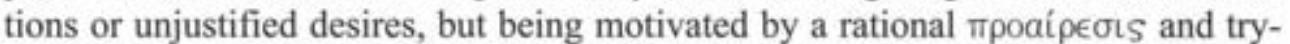
ing to accomplish what is honourable (тò $\kappa a \lambda o ́ v)^{3}$. In An seni, he regards a political career as "a way of life of a tamed social animal living in an organized society, intended by nature to live throughout its allotted time the life of a citizen and in a manner devoted to honour and the welfare of mankind" (791C: ßíos ífépou kaì

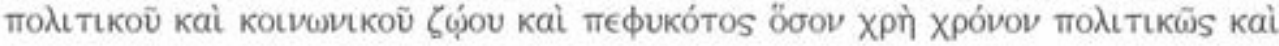

1 Plutarch defends the practice of érrawópowars in De and. poet. 33C-34B.

2 On the question whether Plutarch also succeeded in respecting the other as other, see G. RosKAM, 2004 .

3 See esp. Praec. ger, reip. 798C-799A and 819E-821F; cf. G. RoskAM, 2004/5, and, for the importance Plutarch attaches to a well-founded mpoaipeors, A. WARDMAN, 1974, 107-115 and A. PérEZ JIMÉNEZ, 1995.

José Ribeiro Ferreira, Luc Van der Stockt \& Maria do Céu Fialho (Edd.), Philosophy in Society - Virtues and Values in Plutarch, Leuven-Coimbra, 2008, pp. 195-208. 


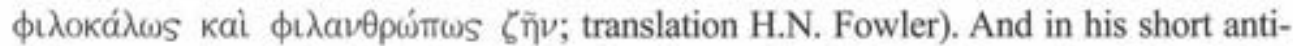
Epicurean polemic De latenter vivendo, he vigorously attacks Epicurus' apolitical ideal of 'living unnoticed' by insisting that well-known politicians did not merely make themselves useful for their fellow citizens $(1128 \mathrm{~F}$ and $1129 \mathrm{BC})$ but that their accomplishments also prove to contribute to their blessedness after death $(1130 \mathrm{C}-\mathrm{E})^{4}$.

The question remains, however, whether human beings should be regarded as being pre-eminently social by nature. Is Plutarch able to put forward convincing arguments in support of his view of human nature? Can he show that social life is not merely the result of our lack of self-sufficiency (cf. Plato, $R$. II, 369b) but also of our social nature ${ }^{5}$ ? The answer is to be found in his short work De amore prolis. Parental love for offspring had long been discussed as the testcase par excellence with regard to the social or asocial nature of man, and Stoics and Epicureans had come to diametrically opposed conclusions ${ }^{6}$.

Unfortunately, this work poses a great number of difficult problems. First of all, the authenticity has occasionally been called into question ${ }^{7}$, although there is no compelling evidence that the work should be regarded as spurious. ${ }^{8}$. Usually, the work's shortcomings are explained by the presupposition that it remained unfinished and was published after Plutarch's death'. Secondly, it is not clear to which literary genre the work belongs. Some scholars seem to think of a greater, more or less systematic treatise, of which De amore prolis would be a fragment or epito$\mathrm{me}^{10}$. Others call it a diatribe $\mathrm{e}^{11}$. Nowadays, it is usually regarded as a declamatio ${ }^{12}$,

On Plutarch's De latenter vivendo, see esp. G. Roskam, 2007a; cf. A. BARIGazzi, 1990, 1. GALLo, 2000 , and U. BERnER et al., 2000, and, for the polemical strategies he uses in this work, G. RoskAM, 2007b.

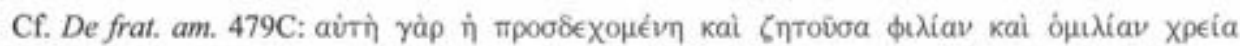

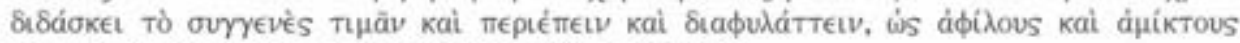

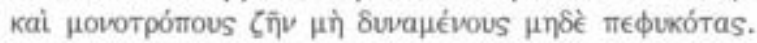

6 For the Stoic conviction that parental love for offspring should be regarded as natural, see, e.g.,

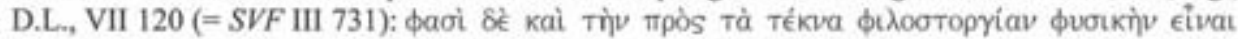

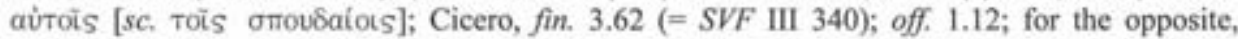
Epicurean position, see Epictetus, 1.23,3-10 (= fr. 525 Us.); Plutarch, De am. prol. 495A (= fr. 527 Us.); Adv. Colot. 1123A (= fr. 528 Us.); cf. also Non posse 1100D; Cicero, Att. 7.2,4 (= fr. 528 Us.); E. PUgliA, 1988.

By B. Weissenberger, 1895, 66-68; cf. also Th. DOEhNER, 1862, 26sqq.

8 The authenticity of De amore prolis was defended by H. PATZIG, 1876, 3-21, and after K. ZIEGLER, 1951,744 , also by all later scholars.

9 See, e.g., W.C. Helmbold, 1939, 328-329; K. Ziegler, 1951, 744; D. BABut, 1969, 74; M. Pohlenz, 1972, 255; J. Dumortier - J. Defradas, 1975, 182; A. Postiglione, 1991, 141; F. BECCHI, 2000, 206, n. 6. 
in line with its markedly rhetorical character, even though one might rather consider it to be a beautiful example of a rhetorical thesis ${ }^{13}$. Thirdly, there is the problem of the date of the work. Usually, its rhetorical character ${ }^{14}$ and aspects of its content ${ }^{15}$ are regarded as indications that De amore prolis is a work of Plutarch's youth, but no argument is really conclusive, and one may add that the study of its prose rhythm does not confirm an early date ${ }^{16}$. Fourthly, it is far from clear which sources Plutarch used in writing De amore prolis. More than once, it has been argued that Plutarch made use of a Stoic source ${ }^{17}$, but this view has also been refuted ${ }^{18}$, and parallels have been established between Plutarch's position in De amore prolis and Peripatetic doctrine ${ }^{19}$. Fifthly, Plutarch's argumentation itself raises several problems, since there can be found embarrassing inconsistencies between different passages in the work and between Plutarch's position in De amore prolis and his views in other works. This immediately entails yet another question, viz.: what is the place of De amore prolis within the whole Corpus Plutarcheum? Of course, the determination of the principal theme of the work is important for its classification, but even on this question opinions greatly differ ${ }^{20}$.

This brief survey sufficiently shows that De amore prolis is not Plutarch's easiest work, and that more than one point remains open to discussion. Of course it is not my intention to discuss all these questions in this contribution. In what follows, I'll focus on one aspect of the work that has not yet been examined and which to my mind may well contribute to a better understanding of its content and scope, that is, the polemical methods and eristic strategies which Plutarch uses in it in order to refute Epicurus' position.

K. Ziegler, 1951, 743; M. Pohlenz, 1972, 255; A. Postiglione, 1991, 141; A. Barigazzi, 1994, 171; R. CABAllero SÁNChez, 1999a, 107, n. 6; ID., 1999b, 550.

13 Cf. B. Heininger - R. Feld meier, 2000, 39 on Plutarch's De latenter vivendo; for the parallel between De latenter vivendo and De amore prolis, see A. BARIGAZZI, 1994, 144-145.

14

15

16

17

18

19

20

Cf., e.g., K. Ziegler, 1951, 744 and A. BARIGAZ7I, 1994, 171.

Cf. D. BABUt, 1969, 78 and A. Postiglione, $1991,142$.

See F.H. SANDBACH, 1939, 196-197.

See, e.g., A. DYrofF, 1897, 38, with n. 4; A. MAYER, 1910, 563 and R. CABALlero SÁnchez, 1999 b.

D. BАвUT, 1969, 76.

A. BARIGAZZI, 1994, 159 and passim.

The work has been regarded as a discussion of the Stoic theory of oikeíwoIS (R. CABALLERo

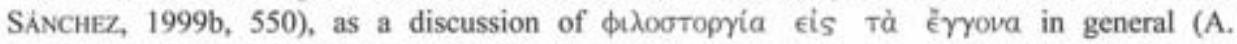
Postiglione, 1991, 140), as an attack on the wickedness of Plutarch's contemporaries (G. SANTESE, 1999, 50 and 59; cf. also E. TeIXeIrA, 1982, 29-30 and 41), or as an anti-Epicurean polemic (which is the view to which I would give preference; A. BARIGAZZI, 1994, 169; cf. also K. ZIEGLER, 1951, 743). 
It is very important indeed to see that the whole work should be regarded as a polemical attack against Epicurus' notorious conviction that parental love for offspring is not natural. This conviction is attacked in De amore prolis by means of five successive arguments, which I'll examine one by one.

\section{The 'argument from the animals'}

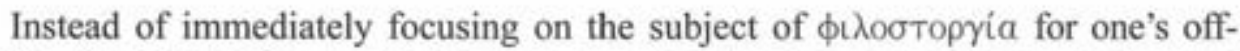
spring, Plutarch begins the work with a general reflection on the 'argument from the animals'. He points out that this argument is often used in philosophical discussions, and suggests two possible reasons that might explain this custom. On the one hand, irrational animals remain impartial, and present as it were 'objective' evidence; on the other hand, the custom can be interpreted as a charge against the wickedness of human beings, who look for rules of conduct in animals as if they lacked indications of nature in themselves (493A-C). After these more general reflections, Plutarch turns to the subject of what is in agreement with nature in animals with regard to marriage (493E), and proceeds by drawing a highly idealized picture of animal sexual behaviour, illustrated by many concrete examples (493E-494F). All this is clearly traditional material, which Plutarch had at his disposal and which he could use and reuse in different contexts ${ }^{21}$. Plutarch clarifies the relevance of all the examples in what follows: nature has not (only) produced these emotions in animals because she takes thought for their offspring, but (also) in order to give examples for those who want to follow her, and to blame the insensibility $(\dot{a} \pi \dot{\theta} \theta \epsilon t a)$ of unfeeling people $(494 \mathrm{~F}-495 \mathrm{~A})^{22}$. The latter turn out to be the Epicureans. Indeed, Epicurus' philosophical position implies - according to Plutarch - that human nature is the only one that does not know disinterested affection, and only loves because of utility ( $\chi \rho \in i \alpha)$, or for pay ( $\mu$ $\sigma \theta_{\circ}$ ). Such a position would be rejected, always according to Plutarch, by the animals themselves, and should be regarded as shameful (495AB).

With this attack on Epicurus' conviction, Plutarch finally arrives at the central theme of his work. His elaborate discussion of the conduct of animals now proves to be a first argument against the Epicurean position: conclusions concerning the natural behaviour of the beasts, based on careful observation of 'plain facts', can be extrapolated to human beings.

A systematical analysis of such repetitive clusters of traditional material repays the efforts it requires, in that it throws interesting light on Plutarch's method of working; see, e.g., L. VAN DER STOCKT, 1999.

22 For other examples of this anthropocentric view, which was common in ancient thinking, see Xenophon, Mem. 4.3,9-10; Aristotle, Pol. I, 1256bl5-22; Cicero, nat. deor. 2.37 (=SVF II 1153) and 2.154-162; Porphyry, Abst. 3.20,1-2 (= SVF II 1152); Origen, Cels. 4.54 (= SVF II 1155); Epictetus, $1.6,18 ; 1.16,1-5 ; 2.8,6-8$. 
Several polemical strategies can already be found in this first argument. First of all, it is striking that Epicurus' position is nowhere discussed in detail. The specific Epicurean doctrine is completely isolated from its original context, and Plutarch nowhere mentions Epicurus' arguments for his view ${ }^{23}$. Secondly, the Epicurean tenet is not merely presented in all its radicalness, it is also misrepresented to a certain extent by interpreting the component of usefulness in a financial way: parents love their children not merely because they derive some use from them: they love them for pay. That this is not what Epicurus wanted to say is obvious of course. Thirdly, by this misrepresentation, Plutarch succeeds in disqualifying Epicurus on

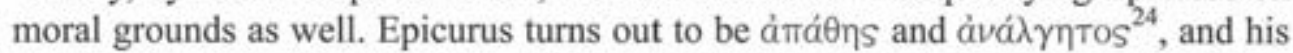
position is shameful (aioxpóv). Finally, Plutarch's polemical argument also illustrates the superiority of his own position, both from an intellectual and from a moral perspective, and thus invites approval of his own position and rejection of the Epicurean alternative. The many traditional examples brought forward by Plutarch indeed give evidence of his remarkable erudition, and his meta-reflections at the very beginning of the work on the general value of the argument from the animals suggest a careful and well-considered approach.

\section{Man as a social being by nature}

After a short and quite emphatic rejection of Epicurus' position (495B), Plutarch introduces an important new argument. He first compares wild plants, which have already imperfect principles of cultivated fruits, with beasts, which show imperfect love for offspring, and then opposes both to man, a rational and social animal

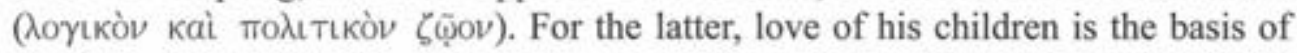
justice, law, the worship of the gods, the founding of cities, and friendliness (495BC). This is an important passage in De amore prolis, and again, Plutarch makes use of several interesting polemical strategies.

First of all, the passage places the preceding reflections in a somewhat different perspective. Plutarch's understanding of the concept of 'nature' now proves more nuanced, which leads to a completely different hierarchy in the scala naturae. For now, it are human beings, and not the plants, who are placed at the top. This apparent inconsistency between the two chapters has received much attention. F. Becchi has shown that the different perspectives can be reconciled with one another ${ }^{25} .1$ would add that the apparent inconsistencies can to an important extent be traced

One may note in passing that Plutarch actually blames Colotes for precisely the same approach; see Adv. Colot. 1108D.

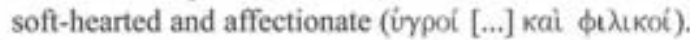

F. BECCHI, 2000. 
back to Plutarch's polemical strategies. For indeed, Plutarch's first intention here is not to develop his own position towards the psychology of animals, but to refute Epicurus' view. To that purpose, he uses different arguments concerning animals, which often find their origin in different sources or philosophical traditions. Plutarch, in short, takes his arguments where he can find them.

This, however, is not the only polemical strategy which Plutarch uses in this passage. By regarding love for one's offspring as the basis for a whole social ethics, Plutarch basically adopts the well-known analogous Stoic position, although he introduces the Stoic idea (which originally belonged to the more general doctrine of

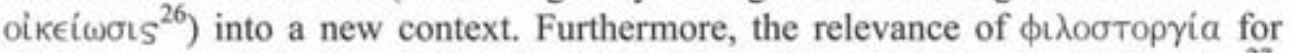
social life seems to be even broader in Plutarch's view than in that of the Stoics ${ }^{27}$. Indeed, Plutarch also connects love for one's children with the worship of the gods. This addition may find its origin in Plutarch's polemical aims. Elsewhere, in any case, he often condemns Epicurus for his atheistic convictions ${ }^{28}$. Finally, one should note that by using the Stoic doctrine against Epicurus, Plutarch tries to isolate his opponent even more. The fact that Plutarch elsewhere questioned (aspects of) the Stoic doctrine of oikeí $\omega \sigma \mathrm{sS}^{29}$ shows that he here adopts it merely pour le besoin de la cause, that is, for his anti-Epicurean polemical argument. The impression is created that Epicurus is the only one who dares to reject the consensus omnium.

\section{The corporeal constitution of man}

With the following reflections on the constitution of the human body, a new argument is introduced. The whole argument presupposes a teleological view of nature (495C), which returns also elsewhere in Plutarch ${ }^{30}$ and which was defended before by Aristotle and by the Stoics ${ }^{31}$. Of this general, teleological perspective, two

26

27

28

29

30

31

See on this doctrine the classical studies of C.O. Brink, 1955/6, S.G. PembrokE, 1971, N.P. White, 1979, G. Striker, 1983, and T. ENGBerg-Pedersen, 1990.

That the Stoics regarded natural $\phi$ i

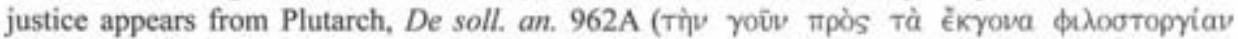

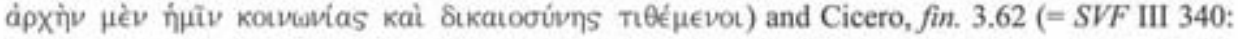
pertinere autem ad rem arbitrantur intellegi natura fieri ut liberi a parentibus amentur; a quo initio profectam communem humani generis societatem persequimur). Not all the details of the Stoic view are perfectly clear, however; ef. B. INwOOD, 1983, 196-199.

See, e.g., De sup. 164F-165A; Non posse 1100C and 1101B; Adv. Colot. 1119C; 1119EF; 1124D; 1125D-F; De lat. viv. 1129B and 1130C.

9 See, e.g., De Stoic. rep. 1038BC and De comm. not. 1060B-D; cf. also De soll. an. 960Dsqq.; discussion can be found in R. CABALL.FRo SANCHEZ, 1999a and b.

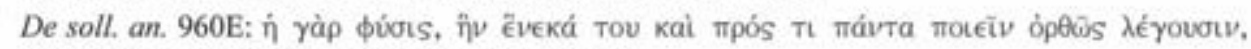
кт ג; Quaest. conv. III, 1, 646C and VII, 1, 698B.

For Aristotle, see, e.g., Pol. 1, 1253a9 and 1256b20-21 (more passages can be found in S.-T. TEO- 
concrete applications are given. The first one, which is about the sexual organs, is merely mentioned in passing (495CD). This elegant praeteritio might have compositorial advantages ${ }^{32}$, to be sure, but is no doubt also motivated by polemical reasons. It is well known indeed that Epicurus was frequently blamed for his supposed sexual debauchery. Of course this widespread prejudice was unjustified ${ }^{33}$, as Plutarch no doubt knew himself ${ }^{34}$. Still, in other anti-Epicurean polemics he likewise takes advantage of these common prejudices ${ }^{35}$, realizing very well that suggestive insinuation on this point yields an easy polemical success. The fact that he is in other contexts much less reticent on sexual topics ${ }^{36}$ also shows that his praeteritio here finds its raison d'être in a subtle polemic.

The second application is about the production of mother's milk (495D-496A). Contrary to the previous application, this one is elaborated at length. Again, Plutarch makes it clear that his detailed medical discussion (cf. Aem. 14,3-4) should be placed into a general teleological perspective (495D and 496A), from which it also derives its relevance to his anti-Epicurean argument: all corporeal changements a woman undergoes during pregnancy and after giving birth would have been useless if nature had not produced in mothers affection for their children (496A). This argument, which returns in Stoic sources ${ }^{37}$, is further motivated by pointing to the condition of a newborn baby, who, due to his ugliness, is only cared for by someone who shows a natural love (496B; cf. Amatorius 758A).

Plutarch's words here recall the traditional debate on the condition of human beings at the moment of birth. In this argument can be found several polemical strategies which were already used earlier in the work. The detailed, even somewhat pedantic medical discussion once again illustrates Plutarch's great erudition and thus in its own way contributes to the credibility of the author. And by basically agreeing with the Stoic point of view, Plutarch once again tries to isolate Epicurus. These two strategies (that is, isolating the opponent and underlining one's own erudition) also make their influence felt in his quotation from Homer (Il. 17.446-447)

Dorsson, 1989, 293); for the Stoics, see, e.g., Alexander of Aphrodisias, Fat. 11, p. 179.30-31 Bruns (= SVF II 1140); Marcus Aurelius, V 16.

CF. A. BARIGAZZI, 1994, 149-150.

It may have originated in Timocrates' unfair attack on Epicurus; see D. SEDLEY, 1976.

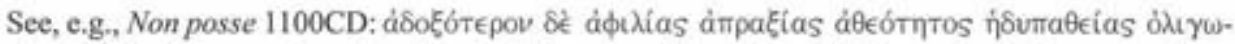

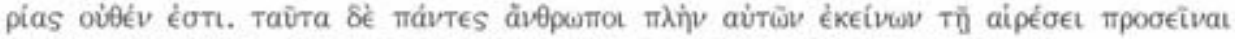

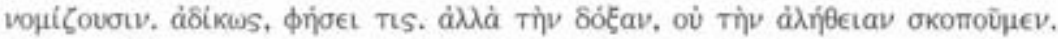

Cf., e.g., Non posse 1089C; 1094C; 1097DE; 1098B; 1099B; De lat. viv. $1129 \mathrm{~B}$.

See, e.g., Quaest. comv. III, 6 on the question of the suitable time for coition.

See esp. Cicero, fin. 3.62. A similar argument, though focusing on the love of a living being for himself, is to be found in D.L. VII 85 and Hierocles, 6.40-43. 
and his allusion to the famous topos of the nakedness and helplessness of man at his birth $^{38}$. One may add here that such quotations and allusions to traditional doctrines are actually omnipresent throughout the whole of the work. Plutarch thus subtly suggests that his attack is supported by many illustrious authorities and that the whole of the Greek intellectual tradition rises in protest against Epicurus' infamous doctrine.

\section{The situation of primitive mankind}

The next argument against Epicurus' view Plutarch borrows from the condition of primitive mankind. One could reasonably expect that at that early moment, mothers were harsh against their children, since they had suffered terrible labour pains and had no prospect of any return. The contrary is true, however: even immediately after having given birth and while still suffering, the primitive mother took care of her baby, which shows that she loved the child not because of her own benefit but by nature (496C-E). Again, Plutarch connects his own position with the authority of traditional thinking (a cultivated reader will easily recognize his allusion to Socrates' argument in Xenophon's Memorabilia 2.2,5), and he tries to make the argument even more convincing by transposing it to the context of primitive mankind. Indeed, at that moment, there was less influence of human culture and less place for the element of utility. Furthermore, one should note that Plutarch elsewhere too points to the situation of the maגatoi as an argument for his own position $^{39}$. An interesting example, proposed in an anti-Epicurean context as well, can be found in De latenter vivendo, where Plutarch regards the custom of primitive people to submit their sick to public inspection as an argument against Epicurus' advice to pursue an unnoticed life (1128E). In both cases, the reference to the conduct of the maגatoi functions as an angumentum ex auctoritate that strongly supports Plutarch's own philosophical position. The fact that the Epicureans themselves gave much attention to the early history of mankind ${ }^{40}$ of course adds an extra dimension to Plutarch's polemical argument. To a certain extent, he tries to defeat Epicurus on his own domain. In that sense, the passage may even contain the seeds of yet another polemical strategy, that is, the attempt to refute the opponent while taking into account his own perspective. However, since Plutarch in this passage never explicitly thematizes the Epicurean genealogy but merely elaborates his own alternative view, one cannot but conclude that he refrained from using in this context the opportunities offered by internal criticism.

Cf., e.g., Plato, Prt. 321c; Lucretius V 222-234; Pliny, nat. 7.1-5; Seneca, epist. 121.6. The opposite view is defended by Xenophon, Mem. 1.4,4-4,14 and 4.3,3-3,14.

See, e.g., Quaest. conv. VIII, 8, 729EF and De esu I, 993C-994B.

40

As appears from Lucretius' book V, from Hermarchus' discussion of ancient legislation concerning homicide in his treatise Against Empedocles, and from Colotes' arguments at the end of his work П€

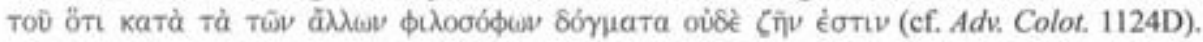




\section{The contemporary situation}

In what follows, the argument derived from primitive mankind is completed by another one which deals with Plutarch's contemporaries (Tois vĩv). Just like their ancient predecessors, they have no prospect of gain, since for human beings, the process of education takes much efforts and time, so that most fathers only know the imperfect behaviour of their sons, and never witness their virtue. Nevertheless they, too, continue to rear children, and most of all those who least need them (496E-497A). This addition leads to one particular application which brings the second argument to a head. Those who least need children are the rich, since they have no need of a child in order to support or bury them, nor in order to have an heir. For a childless rich man can easily find heirs who are much more grateful than his own children would have been. If the rich nonetheless continue to rear children, their behaviour obviously illustrates the power of nature (497A-C). It is clear that the case of the rich man was especially interesting for Plutarch in the context of De amore prolis, because it shows the greatest contrast between having children and utility, and thus casts the greatest doubt on Epicurus' conviction. This illustrates one of the typical strategies present in so many philosophical polemics, that is, the tendency to radicalisation.

Furthermore, this passage also illustrates another interesting polemical strategy used by Plutarch. He does not hesitate to take advantage of moral depravity if it suits his own purpose. It is interesting to note indeed that his argument presupposes wicked behaviour, being based on the premisse that children are not grateful to their parents and do not show them due respect. It is clear of course that such a behaviour is diametrically opposed to Plutarch's own moral ideals ${ }^{41}$. Now one could argue that Plutarch here merely describes how things are, not how they should be, and that by adopting a descriptive rather than a normative view, he wishes to show how aspects of real life refute Epicurus' conviction. Such an interpretation, however, risks to neglect the fact that the evaluation of how things are is at least partly determined by the perspective in which this evaluation is presented. Musonius Rufus, for instance, expresses a completely different judgement of real life, underlining that a man who has many children is highly esteemed ${ }^{42}$. Both authors clearly present a biased evaluation of 'reality' that perfectly suits their respective purposes.

\section{Conclusion}

In the last chapter of the work, Plutarch's polemic takes a somewhat unexpected turn. He does not adduce further arguments against Epicurus' tenet but instead tries to refute possible objections against his own position. Suicide and the exceptional examples of animals which destroy their young cannot really be regarded as

See, e.g., De frat. am. 479F-480A.

42

See fr. XV A, p. 78.14-18 H. 
evidence against his view of natural love for offspring (497CD), and the fact that poor people do not rear their own children even turns out to justify his position (497E). This is again a brilliant application of several polemical strategies. By offering at the end an extensive refutation of possible counter arguments, Plutarch subtly suggests that Epicurus could find no other arguments in support of his own position, and at the same time once again shows that his approach is careful and wellconsidered to the very end, and thus can be trusted and approved.

Plutarch never showed sympathy for Epicurus' philosophy. As was true for most aspects of Epicurean thought, Epicurus' position with regard to parental love for children was diametrically opposed to what Plutarch deemed important. Accordingly, he adopted in an intelligent way different polemical strategies to refute this position.

It is interesting to add, by way of conclusion, that Plutarch in his Consolatio ad uxorem repeatedly emphasized the great pleasure he derived from his little daughter $(608 \mathrm{C} ; 608 \mathrm{EF} ; 610 \mathrm{E})$. The reader of De amore prolis cannot but conclude that these feelings of pleasure were only one aspect of his parental love, and that Plutarch wanted to base them on a more fundamental foundation, which would finally enable him to be both a respected philosopher and a good father.

\section{BIBLIOGRAPHY}

BABUT, D.,

- Plutarque et le stoïcisme (Publications de l'Université de Lyon), Paris, 1969.

BARIGAZZI, A.,

- "Una declamazione di Plutarco contro Epicuro: il De latenter vivendo", Prometheus, 16 (1990) 45-64.

- "Ancora una declamazione contro Epicuro: De amore prolis", in ID., Studi su Plutarco (Studi e testi 12), Firenze, 1994, pp. 141-181.

BECCHI, F.,

- "Irrazionalità e razionalità degli animali negli scritti di Plutarco", Prometheus, 26 (2000) 205-225.

Berner, U. - FeldMeier, R. - HeIninger, B. - Hirsch-Luipold, R.,

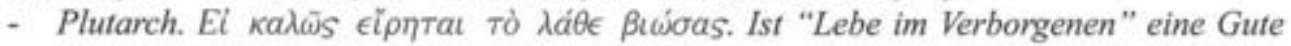
Lebensregel? Eingeleitet, übersetzt und mit interpretierenden Essays versehen (Sapere 1), Darmstadt, 2000.

BRINK, C. O.,

- "Oikeíwots and Oik€tótns. Theophrastus and Zeno on Nature in Moral Theory", Phronesis, 1 (1955/6) 123-145.

CABALlero Sánchez, R.,

- "Oikeíwols en Plutarco", in J.G. Montes Cala - M. Sánchez Ortiz de Landaluce R.J. Gallé Cejudo (eds.), Plutarco, Dioniso y el vino. Actas del VI Simposio español 
sobre Plutarco. Cádiz, 14-16 de Mayo de 1998, Madrid, 1999, pp. 105-118 [=1999a].

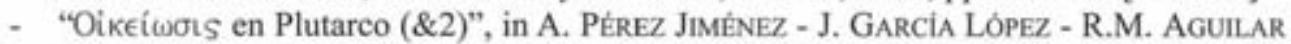
(eds.), Plutarco, Platón y Aristóteles. Actas del V Congreso Internacional de la I.P.S. (Madrid - Cuenca, 4-7 de Mayo de 1999), Madrid, 1999, pp. 549-566 [= 1999b].

DOEHNER, Th.,

- Quaestiones plutarcheae III, Misenae, 1862.

DUMORTIER, J. - DeFradAs, J.,

- Plutarque. Euvres morales, Tome VII - Première partie. Traités de Morale (27-36) (CUF), Paris, 1975.

DYrofF, A.,

- Die Tierpsychologie des Plutarchos von Chaironeia, Würzburg, 1897.

ENGBERG-PEDERSEN, T.,

- The Stoic Theory of Oikeiosis. Moral Development and Social Interaction in Early Stoic Philosophy (Studies in Hellenistic Civilization 2), Aarhus, 1990.

GaLlo, I.,

- Plutarco. Se sia ben detto vivi nascosto, Introduzione, testo critico, traduzione e commento (Corpus Plutarchi Moralium 32), Napoli, 2000.

HARTMAN, J. J.,

- De Plutarcho scriptore et philosopho, Lugduni-Batavorum, 1916.

HEININGER, B. - FELDMEIER, R.,

- "Einleitung", in U. Berner et al., 2000, pp. 33-48.

HELMBOLD, W. C.,

- Plutarch. Moralia, Vol. VI (LCL), London - Cambridge Mass., 1939.

INwoOD, B.,

- 'Comments on Professor Görgemanns' Paper. The Two Forms of Oikeiosis in Arius and the Stoa", in W.W. FortenBaugh (ed.), On Stoic and Peripatetic Ethics. The Work of Arius Didymus (Rutgers University Studies in Classical Humanities 1), New Brunswick - London, 1983, pp. 190-201.

KORUS, K.,

- "Plutarcha 'De amore prolis' 5,497D-E. Próba interpretacji", Eos, 66 (1977) \& 211-220 [Latin summary on p. 220].

MAYER, A.,

- Aristonstudien, Leipzig, 1910 (Philologus. Supplementband 11, pp. 483-610).

PATZIG, H.

- Quaestiones Plutarcheae, diss. inaug., Berolini, 1876.

Pembroke, S. G.,

- "Oikeiosis", in A.A. Long (ed.), Problems in Stoicism, London, 1971, pp. 114-149.

PÉreZ JiMÉNEZ, A.,

- "Proairesis: Las formas de acceso a la vida pública y el pensamiento politico de Plutarco", in I. Gallo - B. SCARDigli (eds.), Teoria e prassi politica nelle opere di Plutarco. Atti del V Convegno plutarcheo (Certosa di Pontignano, 7-9 giugno 1993), Napoli, 1995, pp. 363-381. 
POHLENZ, M.,

- Plutarchi Moralia, Vol. III (BGT) Leipzig, 1972 [edition by W.R. Paton, M. Pohlenz, and W. Sieveking; De am. prol. is edited by M. Pohlenz].

Postiglione, A.,

- Plutarco. L'amore fraterno. L'amore per i figli. Introduzione, testo critico, traduzione e commento (Corpus Plutarchi Moralium 7), Napoli, 1991.

Puglia, E.,

- "L'amore per i figli nella dottrina di Epicuro (Dem. Lac., PHerc. 1012, coll. LXVI 5 LXVIII)", in B.G. Mandilaras (ed.), Proceedings of the XVIII International Congress of Papyrology. Athens 25-31 May 1986, Athens, 1988, pp. 249-255.

ROSKAM, G,

- "Plutarch on Self and Others", Ancient Society, 34 (2004) 245-273.

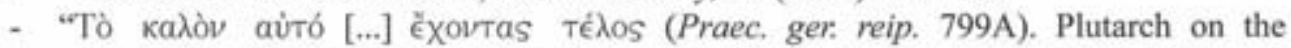
Foundation of the Politician's Career", Ploutarchos. Scholarly Journal of the International Plutarch Society, NS 2 (2004/5) 89-103.

- A commentary on Plutarch 's De latenter vivendo, Leuven, 2007 (=2007a).

- 'Plutarch's attack on Epicurus' ideal of an 'unnoticed life'. Polemical strategies in De latenter vivendo", in J. M. Nieto IBÁÑEZ - R. LÓPEZ LóPEZ (eds.), El amor en Plutarco, León, 2007, pp. 867-876 (=2007b).

SANDBACH, F. H.,

- "Rhythm and Authenticity in Plutarch's Moralia", CQ, 33 (1939) 194-203.

SANTESE, G.,

- Plutarco. Il cibarsi di carne. Introduzione, testo critico, traduzione e commento [a cura di L. INGLese e G. SANTESE] (Corpus Plutarchi Moralium 31), Napoli, 1999 [I refer to the introduction, which was written by G. Santese].

SEDLEY, D.,

- "Epicurus and his Professional Rivals", in J. BolLACK - A. LAKs (eds.), Éfudes sur l'Épicurisme antique (Cahiers de Philologie 1), Lille, 1976, pp. 119-159.

STRIKER, G.,

- "The Role of Oikeiosis in Stoic Ethics", OSAPh, 1 (1983) 145-167.

TEIXEIRA, E.,

- "A propos du De amore prolis et du De fraterno amore: la famille vue par Plutarque", AFLD, 12 (1982) 25-41.

TEODORSSON, S.-T.,

- A Commentary on Plutarch's Table Talks. Vol. I (Books 1-3) (Studia Graeca et Latina Gothoburgensia 51), Göteborg, 1989.

VAN DER STOCKT, L.,

- "A Plutarchan Hypomnema on Self-Love", AJPh, 120 (1999) 575-599.

VOLKMANN, R.,

- Leben, Schriften und Philosophie des Plutarch von Chaeronea, Berlin, 1869.

WARDMAN, A.,

- Plutarch's Lives, London, 1974. 
WEISSENBERGER, B.,

- Die Sprache Plutarchs von Chaeronea und die pseudoplutarchischen Schriften, diss. inaug., Straubing, 1895.

WHITE, N. P.,

- "The Basis of Stoic Ethics", HSPh, 83 (1979) 143-178.

ZIEGLER, K.,

- "Plutarchos von Chaironeia", RE 21.1, Stuttgart, 1951, 636-962. 


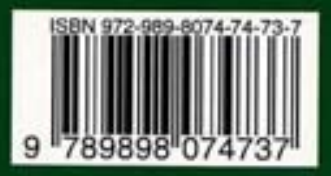

